\title{
Pilot study of ofloxacin and interferon-alpha combination therapy for chronic hepatitis C without sustained response to initial interferon administration
}

\author{
Masafumi Komatsu MD, Tohru Ishii MD, Tsuyoshi Ono MD, Takao Hoshino MD, Tomoyuki Kuramitsu MD, \\ Takashi Goto MD, Tomoo Fujii MD, Itaru Toyoshima MD, Mitsuro Chiba MD, Osamu Masamune MD
}

\begin{abstract}
M Komatsu, T Ishii, T Ono, et al. Pilot study of ofloxacin and interferon-alpha combination therapy for chronic hepatitis $\mathrm{C}$ without sustained response to initial interferon administration. Can J Gastroenterol 1997;11(6):507-511. A controlled trial comparing combination therapy with ofloxacin (OFLX) and interferon (IFN) versus IFN monotherapy was conducted in patients with chronic hepatitis $\mathrm{C}$ who failed IFN therapy. Twenty patients were assigned randomly to two groups. Equal doses of recombinant IFN $\alpha-2 b$ were administered to each group for 24 weeks. For the IFN plus OFLX group, OFLX was administered for 12 weeks at a daily dose of $600 \mathrm{mg}$. Levels of hepatitis $\mathrm{C}$ virus RNA declined significantly from the first month after the start of IFN treatment compared with those before administration in both groups. Serum alanine aminotransferase levels were significantly lower in the IFN plus OFLX group at two and six months after the start of treatment than levels in the IFN group. The fraction of subjects whose levels of serum ALT normalized was also higher in the IFN plus OFLX group. Larger clinical trials should be undertaken.
\end{abstract}

Key Words: Chronic hepatitis C, Combination therapy, Interferonalpha, Ofloxacin
Une étude pilote sur le traitement combiné avec l'ofloxacine et l'interféron-alpha dans l'hépatite $\mathrm{C}$ chronique en l'absence d'une réponse soutenue à une administration initiale d'interféron

RÉSUMÉ : Un essai contrôlé comparant un traitement combiné avec l'ofloxacine (OFLX) et l'interféron (IFN) à une monothérapie à l'IFN a été mené chez des patients atteints d'une hépatite $\mathrm{C}$ chronique et qui n'ont pas répondu au traitement par IFN. Vingt patients ont été randomisés en deux groupes. Des doses égales d'IFN-alpha-2b recombinant ont été administrées à chaque groupe pendant 24 semaines. Dans le groupe IFN-OFLX, l'ofloxacine a été administrée pendant 12 semaines à une dose quotidienne de $600 \mathrm{mg}$. Les niveaux d'ARN du virus de l'hépatite C ont considérablement diminué à partir du premier mois suivant le début du traitement à l'IFN par rapport aux niveaux existants avant l'administration du traitement dans les deux groupes. Les niveaux sériques d'alanineaminotransférase étaient considérablement moins élevés dans le groupe IFN+OFLX à deux et 6 mois après le début du traitement comparativement au groupe traité uniquement à l'IFN. La proportion de sujets dont les niveaux sériques d'alanine-aminotransférase s'étaient normalisés étaient également plus importante dans le groupe IFN-OFLX. Des essais cliniques d'une plus grande ampleur devraient donc être menés.

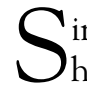
nce its introduction for non- $A$, non-B hepatitis and for hepatitis C (1-3), over 200,000 patients have been treated with interferon (IFN) therapy in Japan. Although this therapy has proven effective, the percentage of patients

with long term normalization of transaminase levels is only $30 \%(4,5)$. Despite an initial response to IFN, some patients relapse after completion of IFN therapy. Some studies have suggested that such a relapse might be prevented by admini-

First Department of Internal Medicine, Akita University School of Medicine, Hondo, Akita City, Japan

Correspondence and reprints: Dr Masafumi Komatsu, First Department of Internal Medicine, Akita University School of Medicine, 1-1-1, Hondo, Akita City, Japan. Telephone 81-18-834-1111, fax 81-18-836-2611

Received for publication January 29, 1997. Accepted May 28, 1997 


\section{TABLE 1}

Patient characteristics at the beginning of the trial

\begin{tabular}{|c|c|c|}
\hline Clinical features & $\begin{array}{c}\text { Group A } \\
\text { (ofloxacin plus interferon) }\end{array}$ & $\begin{array}{c}\text { Group B } \\
\text { (interferon alone) }\end{array}$ \\
\hline Number of patients & 10 & 10 \\
\hline Age (years) & $46.8 \pm 9.6^{*}$ & $44.2 \pm 11.8^{*}$ \\
\hline Sex (male:female) & $8: 2$ & $7: 3$ \\
\hline Alanine aminotransferase $(\mathrm{U} / \mathrm{mL})$ & $95.5 \pm 48.0^{*}$ & $90.4 \pm 54.5^{*}$ \\
\hline $\begin{array}{l}\text { Hepatitis } C \text { virus RNA titres } \\
\quad(\log 10 \text { copies } / \mathrm{mL})\end{array}$ & $7.8 \pm 1.8^{*}$ & $8.2 \pm 1.2^{*}$ \\
\hline Hepatitis $C$ virus genotype (1b:2a) & $8: 2$ & $9: 1$ \\
\hline Liver histology, Histology Activity Index score* & $7.9 \pm 3.6^{*}$ & $7.8 \pm 2.9^{*}$ \\
\hline $\begin{array}{l}\text { Total dose of interferon in initial administration } \\
\quad\left(\text { IU } \times 10^{6}\right)\end{array}$ & $554 \pm 65^{*}$ & $463 \pm 121^{*}$ \\
\hline $\begin{array}{l}\text { Cases with undetectable hepatitis } C \text { virus } \\
\text { RNA at the end of initial interferon } \\
\text { administration }\end{array}$ & $7(70 \%)$ & $7(70 \%)$ \\
\hline $\begin{array}{l}\text { Cases with normalization of alanine } \\
\text { aminotransferase levels at the end of initial } \\
\text { interferon administration }\end{array}$ & $7(70 \%)$ & $6(60 \%)$ \\
\hline $\begin{array}{l}\text { Interval to retreatment from initial } \\
\text { administration (days) }\end{array}$ & $484 \pm 240^{*}$ & $558 \pm 270^{*}$ \\
\hline
\end{tabular}

${ }^{\star}$ Mean $\pm S D$. Differences between groups $A$ and $B$ were not significant

stration of larger dosages of IFN for longer periods (6); however, IFN treatment is costly and is associated with various adverse reactions. These factors have led to attempts at combination therapy with other agents. To date, combination therapy with ribavirin $(7,8)$, ursodeoxycholic acid (9) and azidothymidine (10) have been reported. In 1993, Takada et al (11) reported that ofloxacin (OFLX), a new quinolone derivative, is effective against hepatitis $\mathrm{C}$, and combination therapy with IFN enhanced therapeutic efficacy. We conducted a controlled trial using combination therapy with OFLX and IFN versus IFN monotherapy in patients with chronic hepatitis $\mathrm{C}(\mathrm{CHC})$ who underwent unsuccessful therapy with IFN.

\section{PATIENTS AND METHODS}

Twenty patients with $\mathrm{CHC}$ who had failed therapy with IFN were enrolled in the trial. All patients were positive for hepatitis $\mathrm{C}$ virus (HCV) RNA and had persistently abnormal liver function tests. Tests for the presence of antinuclear antibody and hepatitis B surface antigen were negative in all patients. Biopsy of the liver was performed within the sixmonth period before the start of IFN readministration. Histological studies found chronic hepatitis in all cases. Evaluation was made according to the Histology Activity Index of Knodell et al (12). Initial IFN administration was made more than six months before retreatment in all cases. Before retreatment, neither IFN nor other antiviral agents were administered.

Patients were assigned randomly to two groups - group A, which included 10 patients who received combination therapy with IFN and OFLX; and group B, which included 10 pa- tients who received IFN only (Table 1). Recombinant IFN $\alpha-2 b$ (Schering Plough, New Jersey) was administered at a dose of $10^{6} \mathrm{U}$, six days per week for four weeks from initiation of therapy, and then at the same dose three days per week for 20 weeks. For group A, OFLX was administered for 12 weeks at a daily dose of $600 \mathrm{mg}$ from the fifth week of IFN therapy.

Alanine aminotransferase (ALT) values were measured weekly for one month starting immediately before the start of IFN administration and monthly thereafter.

The HCV genotype was identified by polymerase chain reaction using the type-specific core region primer according to the method of Okamoto et al (13). Types 1, 2, 3 and 4 of the Okamoto et al classification correspond to types $1 \mathrm{~b}, 2 \mathrm{a}$ and $2 \mathrm{~b}$ of the Simmonds et al classification (14). Levels of HCV-RNA were measured by the multicyclic RT-PCR method (15) using the 5 '-noncoding region as a primer. The HCV genotype was determined before IFN treatment. HCV-RNA levels were measured six times - before IFN therapy; at one and four months of IFN therapy; at the end of therapy; and three and six months after therapy.

Antibodies to IFN $\alpha-2 b$ were determined by bioassay just before IFN administration and one month after administration.

For statistical analysis, the Friedman repeated measures ANOVA on ranks test, the Mann-Whitney $U$ test and Fisher's exact test were used. The results were expressed as the mean $\pm \mathrm{SD}$, and $\mathrm{P}<0.05$ was considered statistically significant.

The study was approved by the institutional review board at Akita University School of Medicine, and written informed consent was obtained from all patients. 
TABLE 2

Number of patients with normal alanine aminotransferase levels before and after treatment with ofloxacin plus interferon or with interferon alone

\begin{tabular}{lcccccc}
\hline & \multicolumn{4}{c}{ Number of patients } \\
& $\begin{array}{c}\text { Before } \\
\text { treatment }\end{array}$ & $\begin{array}{c}\text { After } \\
\text { 1 month }\end{array}$ & $\begin{array}{c}\text { After } \\
\mathbf{4} \text { months }\end{array}$ & $\begin{array}{c}\text { At the end of } \\
\text { treatment }\end{array}$ & $\begin{array}{c}\mathbf{3} \text { months after } \\
\text { treatment }\end{array}$ & $\begin{array}{c}\mathbf{6} \text { months after } \\
\text { treatment }\end{array}$ \\
\hline $\begin{array}{l}\text { Ofloxacin plus interferon } \\
\text { (10 patients) }\end{array}$ & 0 & $4(40 \%)$ & $9(90 \%)$ & $10(100 \%)$ & $4(40 \%)$ & $6(60 \%)$ \\
\begin{tabular}{l} 
Interferon alone (10 patients) \\
\hline
\end{tabular} & 0 & $3(30 \%)$ & $4(40 \%)$ & $5(50 \%)$ & $2(20 \%)$ & $1(10 \%)$ \\
\hline
\end{tabular}

TABLE 3

Number of patients with undetectable levels of serum hepatitis C virus RNA before and after treatment with ofloxacin plus interferon or with interferon alone

\begin{tabular}{|c|c|c|c|c|c|c|}
\hline & \multicolumn{6}{|c|}{ Number of patients } \\
\hline & $\begin{array}{c}\text { Before } \\
\text { treatment }\end{array}$ & $\begin{array}{c}\text { After } \\
1 \text { month }\end{array}$ & $\begin{array}{c}\text { After } \\
4 \text { months }\end{array}$ & $\begin{array}{l}\text { At the end of } \\
\text { treament }\end{array}$ & $\begin{array}{c}3 \text { months after } \\
\text { treatment }\end{array}$ & $\begin{array}{c}6 \text { months after } \\
\text { treatment }\end{array}$ \\
\hline $\begin{array}{l}\text { Ofloxacin plus interferon } \\
\quad(10 \text { patients })\end{array}$ & 0 & $5(50 \%)$ & $8(80 \%)$ & $7(70 \%)$ & $2(20 \%)$ & $2(20 \%)$ \\
\hline Interferon alone (10 patients) & 0 & $5(50 \%)$ & $7(70 \%)$ & $7(70 \%)$ & 0 & 0 \\
\hline
\end{tabular}

\section{RESULTS}

In group A, serum ALT levels fell after one month of IFN treatment. After two months (after one month of OFLX combination therapy), until the end of the therapy, serum ALT levels were significantly lower than those before administration $(\mathrm{P}<0.01)$. Levels rose once after therapy but declined after six months. In group B, serum ALT levels began to decline after one month of therapy, and by six months were reduced significantly compared with pretreatment levels $(\mathrm{P}<0.05)$. Similar to results in group A, serum ALT levels rebounded transiently six months after completion of therapy. The decline in ALT levels was more marked in group A than in group B. Although no difference in serum ALT levels was present after the first month of IFN therapy, ALT levels in group A were significantly lower at two, four and six months $(\mathrm{P}<0.05)$ (Figure 1). No significant difference in the fraction of subjects whose serum ALT levels normalized after the first month of IFN therapy was observed. By the fourth month, ALT normalization rates for groups $\mathrm{A}$ and $\mathrm{B}$ were $90 \%$ and $40 \%$, respectively. After the sixth month of therapy, the normalization rate in group A was higher than that in group B (Table 2). Moreover, the fraction of cases that maintained normal ALT levels six months after therapy was still higher in group A (40\%) than in group B (10\%).

HCV-RNA levels were significantly lower after the first month of IFN therapy for both groups $(\mathrm{P}<0.05)$. Levels continued to decline after four and six months of therapy. However, levels relapsed after completion of therapy in both groups and were lower in group A (Figure 2). No significant difference in the rate of HCV-RNA clearance was observed. In fact, only two cases in group A remained HCV-RNA negative three and six months after therapy (Table 3 ).

Neutralizing antibodies to IFN $\alpha-2 b$ were absent in all cases just before IFN therapy; however, neutralizing antibod-

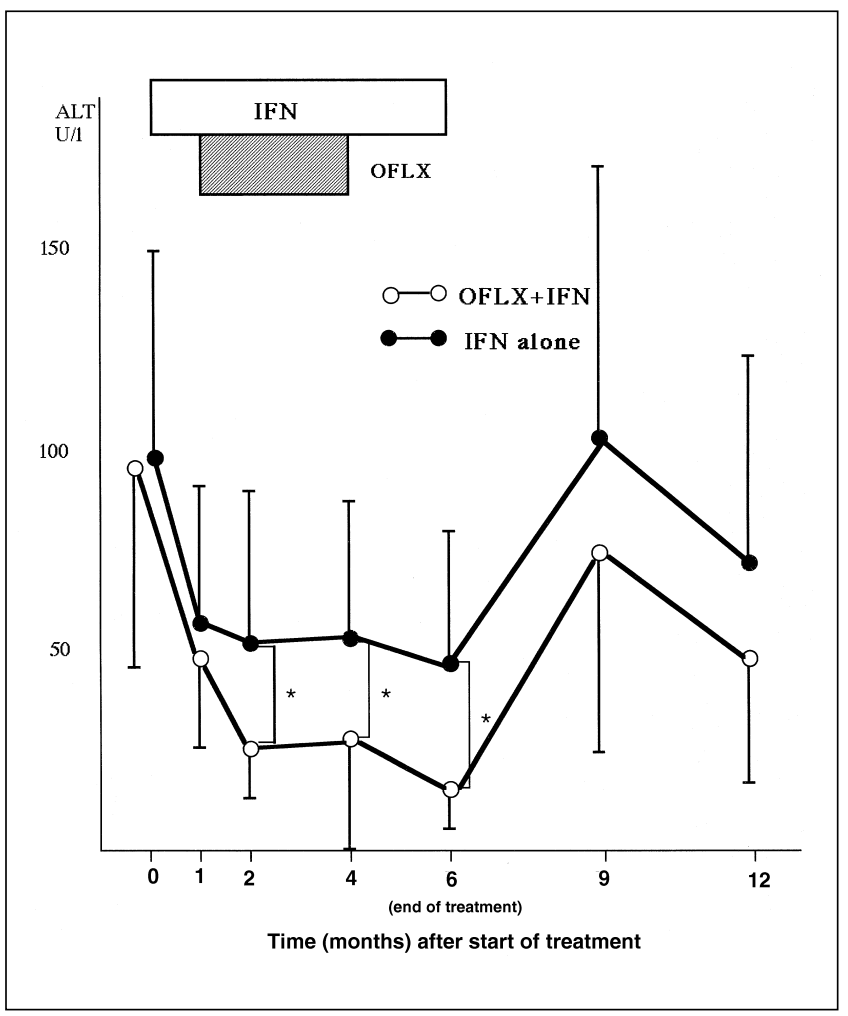

Figure 1) Changes in serum levels of alanine aminotransferase (ALT) in patients treated with interferon (IFN) plus ofloxacin (OFLX) or IFN alone. Recombinant IFN $\alpha 2 b$ was administered for six months at a daily dose of $10^{6} \mathrm{U}$. OFLX was administered for three months at a daily dose of $600 \mathrm{mg}$. Data presented as the mean \pm SD. $* P<0.05$

ies to IFN $\alpha-2 b$ were detected in one patient in group $\mathrm{A}$ one month after the end of therapy.

As for side effects, influenza-like symptoms were observed in all cases, for which analgesics were administered. After 


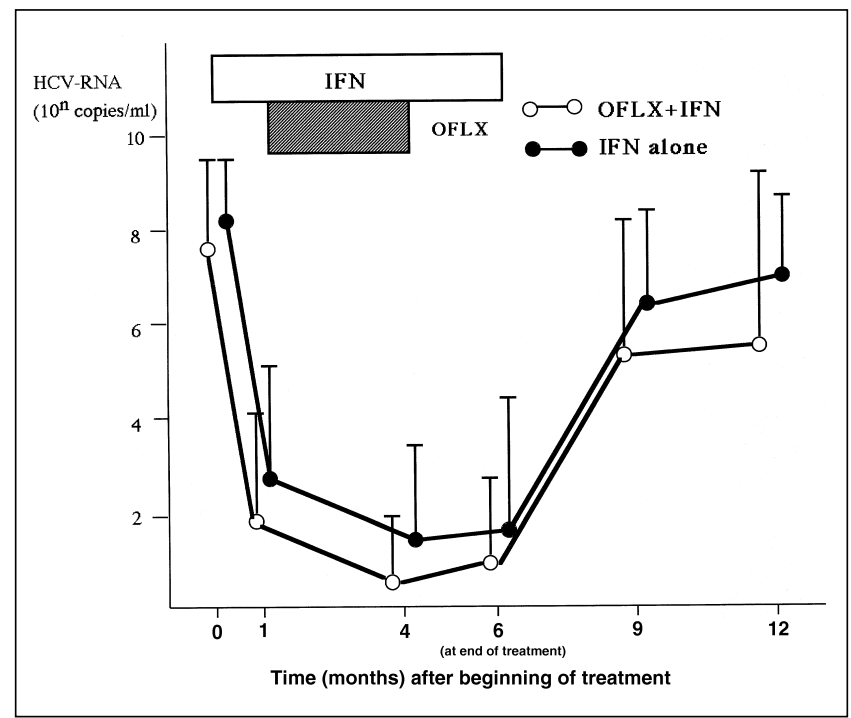

Figure 2) Changes in serum levels of hepatitis C virus (HCV) RNA in patients treated with interferon (IFN) plus ofloxacin (OFLX) or IFN alone. Recombinant IFN $\alpha 2 b$ was administered for six months at a daily dose of $10^{6} \mathrm{U}$. OFLX was administered for three months at a daily dose of $600 \mathrm{mg}$. Data presented as mean $\pm \mathrm{SD}$

five months of therapy one patient in group A became depressed and IFN administration was suspended. This patient was included in the analysis, and the total IFN dose reached $600 \times 10^{6}$ IU. Mild diarrhea was reported by one patient in group A.

\section{DISCUSSION}

OFLX was developed as a new quinolone derivative and has been widely used as an antibacterial agent throughout the world. OFLX inhibits topoisomerase activity and propagation of DNA viruses such as vaccinia virus and herpes simplex virus (17). OFLX reportedly inhibits reverse transcriptase of murine and avian retroviruses, which are both RNA viruses (18). Moreover, a therapeutic effect on HIV infection has been reported (19). Takada et al (11) provided the first report of increased rates of remission with combination therapy with IFN for HCV infection. No randomized, controlled trials have been performed to investigate this specific form of combination therapy. In the present study, we conducted a randomized, controlled trial comparing IFN monotherapy with IFN plus OFLX combination therapy in patients with intractable $\mathrm{CHC}$ who failed to obtain a long lasting remission with initial IFN therapy.

Most studies have reported that patients in whom IFN retreatment was effective demonstrated a favourable antiviral effect during initial IFN treatment, with serum HCVRNA levels that did not rebound at the start of retreatment. Moreover, the IFN dose with retreatment was greater than that of the initial treatment (20-22).

In the present study, serum HCV-RNA levels were not detectable at the end of initial IFN therapy in 50\% of the patients. It is possible that this effect represents an initial response to IFN therapy. The total IFN dose in the initial therapy was over $400 \times 10^{6} \mathrm{U}$ in all cases. Therefore, in the second trial we set the total dose at $840 \times 10^{6} \mathrm{U}$. In addition, to investigate the antiviral and synergistic effects of combination therapy with OFLX on transaminase levels, concomitant administration of OFLX was initiated one month after the start of retreatment and continued for three months. As a result, HCV-RNA levels at three months after the concomitant use of OFLX were lower than levels before the institution of OFLX. However, similar results were obtained with use of IFN alone. Thus, we were not able to verify the synergy of combination therapy against HCV-RNA. On the other hand, we observed that two patients became $\mathrm{HCV}$ RNA positive after discontinuing OFLX, despite continuation of IFN therapy. The rate of ALT normalization was higher in the combination group. Forty per cent of the patients maintained normal levels for more than six months after the end of IFN therapy. Among these, two cases demonstrated long term clearance of HCV-RNA. To verify these findings, larger clinical trials should be undertaken.

The mechanism of the effect of OFLX on HCV infection is not clear. Takada et al (11) reported that levels of HCVRNA and ALT declined in three of nine patients with $\mathrm{CHC}$ to whom only OFLX had been administered (200 to $900 \mathrm{mg}$ / day). Although favourable effects were reported in patients who were administered doses of $600 \mathrm{mg} /$ day or greater, we set the dose of OFLX at $600 \mathrm{mg} /$ day. This dose was limited by the development of diarrhea and anorexia in patients given $900 \mathrm{mg} /$ day. As a result, mild diarrhea occurred in only one patient. In the combination therapy group, one patient demonstrated depression, which was alleviated by the suspension of IFN therapy and concomitant administration of depressant medication. Frequent reports of depression associated with administration of IFN are present in the literature. However, the contribution of OFLX is not known.

Neutralizing antibody to IFN $\alpha-2 b$ was observed in one patient in the combination therapy group one month after the end of therapy. In that patient, a favourable decline in ALT levels was observed at the start of therapy. These levels rebounded after three months and normalized once again at the end of therapy, only to remain elevated thereafter. HCV-RNA was persistently positive in this patient. Roffie et al (23) demonstrated the emergence of a neutralizing antibody against IFN as a cause of the re-elevation of ALT levels - a so-called breakthrough occurring during IFN therapy. Because retreatment may simulate an effect, attention should be paid to the emergence of this antibody.

ACKNOWLEDGEMENTS: We thank Professor Akira Takada of the Division of Gastroenterology, Department of Internal Medicine, Kanazawa Medical University for guiding us in OFLX administration.

\section{REFERENCES}

1. Hoofnagle JH, Mullen KD, Jones DB, et al. Treatment of chronic non-A, non-B hepatitis with recombinant human alpha interferon. N Engl J Med 1986;315:1575-8.

2. Di Bisceglie AM, Martin P, Kassiandies C, et al. Recombinant interferon alpha therapy for chronic hepatitis C. A randomized, double-blind, placebo-controlled trial. N Engl J Med 1989;321:1506-10. 
3. Omata M, Ito Y, Yokosuka O, et al. Histological changes of the liver by the treatment of chronic non-A, non-B hepatitis with recombinant leucocyte interferon alpha: Comparison with histological changes in chronic hepatitis B. Dig Dis Sci 1989;34:330-7.

4. Terada M, Baba T, Ota M, et al. [Interferon treatment for chronic hepatitis C: Assessment of 3 regimens in patients who received more than $500 \mathrm{MU}$ interferon treatment and their effect as predictive factors for interferon treatment using multivariate analysis with the logistic regression model]. Jpn Gastroenterol 1995;92:56-61.

5. Toyoda H, Nakano S, Kumada T, et al. [Clinical study of efficacy of interferon alpha for chronic hepatitis C: evaluation according to effectiveness and background]. Acta Hepatol Jpn 1994;35:481-7.

6. Kasahara A, Hayashi N, Hiramatsu N, et al. Ability of prolonged interferon treatment to suppress relapse after cessation of therapy in patients with chronic hepatitis C: Multicenter randomized controlled trial. Hepatology 1995;21:291-7.

7. Kakumu S, Yosioka K, Wakita T, Ishikawa T, Takayanagi M, Higashi Y. A pilot study of ribavirin and interferon beta for the treatment of chronic hepatitis C. Gastroenterology 1993;105:507-12.

8. Brillanti S, Garson J, Foli M, et al. A pilot study of combination therapy with ribavirin plus interferon alpha for interferon alpha-resistant chronic hepatitis C. Gastroenterology 1994;107:812-7.

9. Boucher E, Jouanolle $\mathrm{H}$, Ander P, et al. Interferon and ursodeoxycholic acid combined therapy in the treatment of chronic viral C hepatitis: results from a controlled randomized trial in 80 patients. Hepatology 1995;21:322-7.

10. Takada A, Takase S, Tsutsumi M, Sawada M. Effects of azidothymidine on type $\mathrm{C}$ hepatitis. Int Hepatol Commun 1993;1:209-14.

11. Takada A, Takase S, Tsutsumi M, Sawada M. Effects of ofloxacin for type C hepatitis. Int Hepatol Commun 1993;1:272-7.

12. Knodell RG, Ishak KG, Black WC, et al. Formulation and application of a numerical scoring system for assessing histological activity in asymptomatic chronic active hepatitis. Hepatology 1981;1:431-5.
13. Okamoto $\mathrm{H}$, Sugiyama $\mathrm{Y}$, Okada $\mathrm{S}$, et al. Typing hepatitis $\mathrm{C}$ virus by polymerase chain reaction with type-specific primers: Application to clinical surveys and tracing infectious sources. J Gen Virol 1992;73:673-9.

14. Simmonds P, Alberti A, Alter HJ, et al. A proposed system for the nomenclature of hepatitis $\mathrm{C}$ viral genotypes. Hepatology 1994;19:1321-4.

15. Ishiyama N, Katayama K, Ishimi N, et al. Quantitative detection of hepatitis $\mathrm{C}$ virus RNA by multicyclic RT-PCR. Int Hepatol Commun 1993;1:72-9.

16. Stanton GJ, Langford MP, Dianzai F. Virus-yield reduction assay for interferon by titration of Sindbis virus hemagglutinin. Methods Enzymol 1981;78:351-7.

17. Ikeda S, Yazawa M, Nishimura C. Antiviral activity and inhibition of topoisomerase by ofloxacin, a new quinolone derivative. Antiviral Res 1987;8:103-13.

18. Sumiyoshi Y, Nishikawa T, Watanabe T, Kano K. Inhibition of retrovirus RNA-dependent DNA polymerase by novobiocin and nalidixic acid. J Gen Virol 1983;640:2329-33.

19. Nozaki-Renard J, Iino T, Sato T, Marumoto Y, Ohta G, Furusawa M. Fluoroquinolones protect human lymphocyte CEM cell line from HIV-1-induced cytotoxicity. Cell Struct Funct 1990;15:295-9.

20. Arase Y, Kumada H, Chayama K, et al. Interferon retreatment of nonresponders with HCV-RNA-positive chronic hepatitis C. J Gastroenterol 1994;29:299-304.

21. Toyoda H, Nakano S, Takeda I, et al. Retreatment of chronic hepatitis C with interferon. Am J Gastroenterol 1994;89:1453-7.

22. Castillo I, Bartolome J, Navas S, Gonzalez S, Herrero M, Carreno V. Virological and biochemical long-term follow-up of patients with chronic hepatitis $\mathrm{C}$ treated with interferon. Hepatology 1994;19:1342-6.

23. Roffie L, Colloredo G, Antonelli G, et al. Breakthrough during recombinant interferon alpha therapy in patients with chronic hepatitis $\mathrm{C}$ virus infection: prevalence, etiology, and management. Hepatology 1995;21:645-9. 


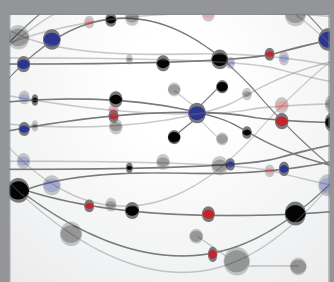

The Scientific World Journal
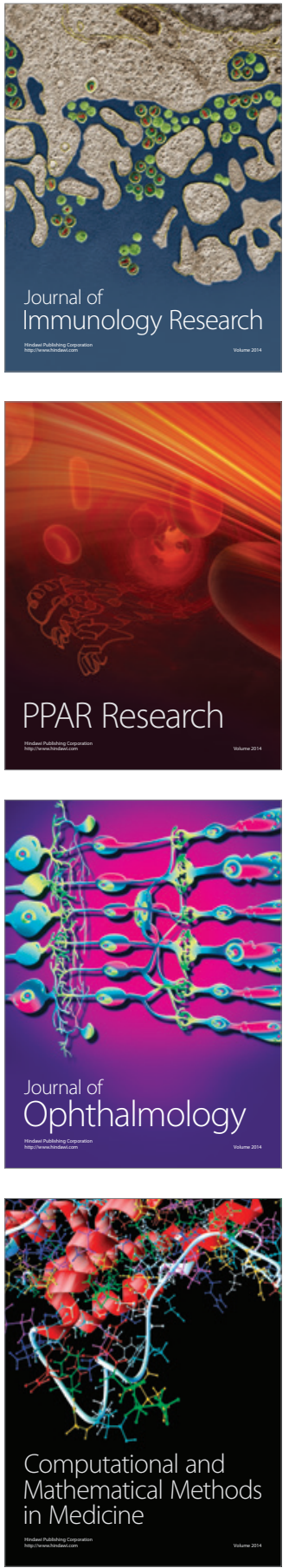

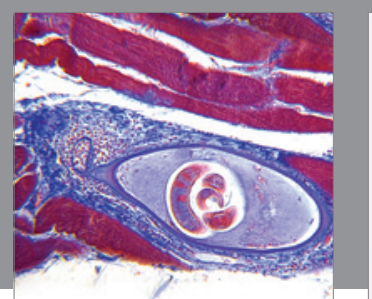

Gastroenterology Research and Practice

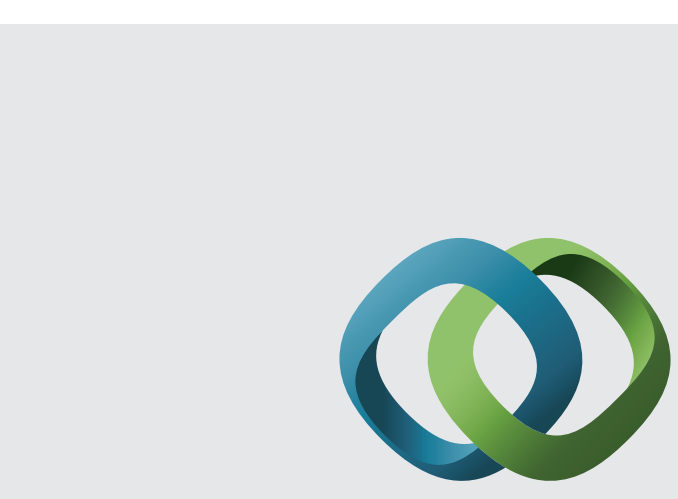

\section{Hindawi}

Submit your manuscripts at

http://www.hindawi.com
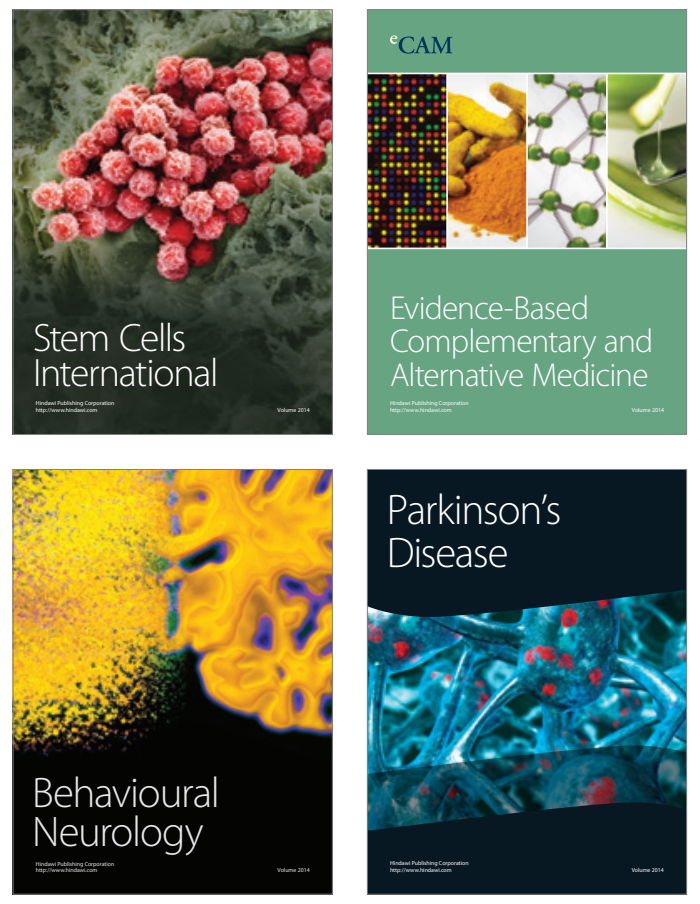
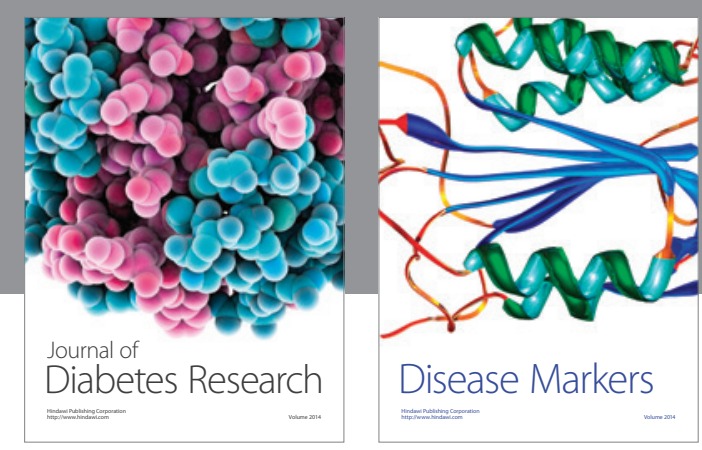

Disease Markers
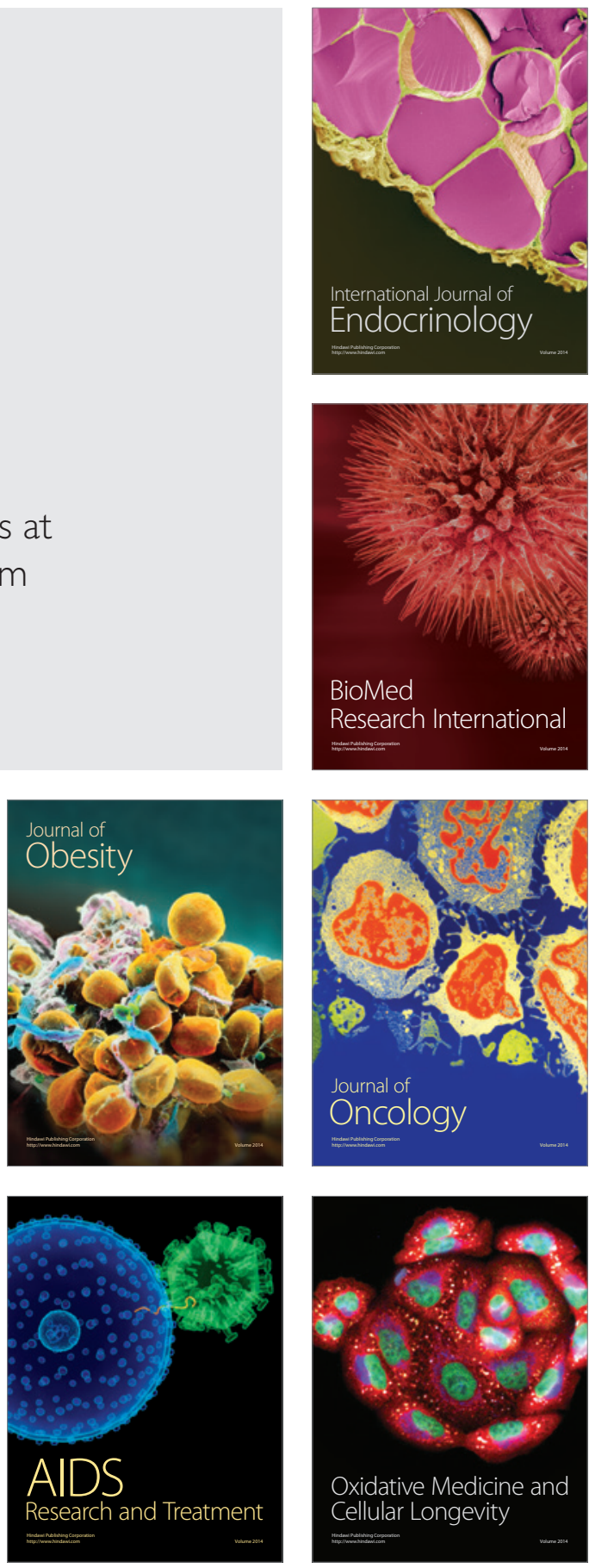